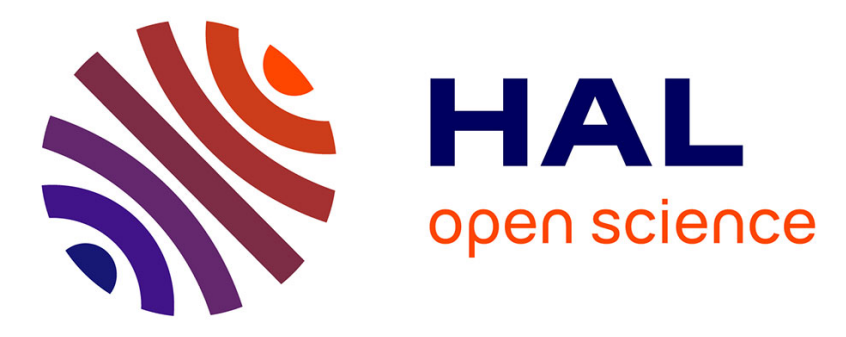

\title{
Estimating the correct way of calculating the carboplatin dose
}

Jesús F. Sierra-Sánchez, Triana González-Carrascosa

\section{To cite this version:}

Jesús F. Sierra-Sánchez, Triana González-Carrascosa. Estimating the correct way of calculating the carboplatin dose. Cancer Chemotherapy and Pharmacology, 2011, 67 (6), pp.1479-1480. 10.1007/s00280-011-1600-5 . hal-00680705

\section{HAL Id: hal-00680705 https://hal.science/hal-00680705}

Submitted on 20 Mar 2012

HAL is a multi-disciplinary open access archive for the deposit and dissemination of scientific research documents, whether they are published or not. The documents may come from teaching and research institutions in France or abroad, or from public or private research centers.
L'archive ouverte pluridisciplinaire HAL, est destinée au dépôt et à la diffusion de documents scientifiques de niveau recherche, publiés ou non, émanant des établissements d'enseignement et de recherche français ou étrangers, des laboratoires publics ou privés. 


\section{Estimating the correct way of calculating the carboplatin dose}

Holweger et al [1] calculated carboplatin administered dose by a modified Calvert formula whereas GFR was substituted by $\mathrm{CrCl}$ via 24-h urine collection or calculated by Jelliffe. We don't know how many patients were dosed with 24-h urine collection or with Jelliffe formula in this study. Observed the measured AUC results $(5.8 \pm 1.1 \mathrm{mg} / \mathrm{mL}$ $x$ min), and the predicted AUC with 24-h urine collection estimation $(4.8 \pm 1.1 \mathrm{mg} / \mathrm{mL} x$ min), it is probably that most patients were dosified using this estimation.

Authors' algorithm and Jelliffe formula are both the most exact formulas, with predicted AUC similar to measured AUC. However, there are some differences in the resources that are necessary for the development of both tests. To use MDRD-6 formula, that is included in authors' algorithm, we need to know serum creatinine, age, sex, ethnicity, blood urea, albumin and BSA. Jelliffe formula doesn't require to know ethnicity, blood urea and albumin, so it could be an easier usage formula with similar results in carboplatin dosage. In addition, it would be interesting to know the results of the prediction using the simplified MDRD-4 IDMS formula, that doesn't need albumin and blood urea values [2].

Calvert formula was developed by using isotopic ${ }^{51} \mathrm{Cr}$-EDTA method to estimate GFR [3]. Romero et al [4] compared, using Calvert formula, ${ }^{51} \mathrm{Cr}$-EDTA method to estimate GFR with Cockcroft-Gault, MDRD-4 IDMS and Wright formula. In this study, that included 290 patients, the best method to estimate GRF was Cockcroft-Gault. In Holweger et al study [1] the Cockcroft-Gault estimation in obese patients was carried out using the actual body weight. It is known that when actual body weight is used, in patients with $\mathrm{BMI}>30 \mathrm{~kg} / \mathrm{m}^{2}$, it can conduce to overdosification. In this case it is recommended to use the ideal or adjusted body weight to apply the Cockcroft-Gault formula [5]. When we use the adjusted body weight in the Cockcroft-Gault estimation for the six obese patients included in the study, the calculated $\mathrm{ClCr}$ is $76 \mathrm{ml} / \mathrm{min}$ $(S D= \pm 17)$. It is probably that this change in the Cockroft-Gault estimation could correct some bias that explains the difference between oGFR (63 $\pm 20 \mathrm{ml} / \mathrm{min})$ and $\mathrm{eCrCl}$ (Cockcroft-Gault) $(75 \pm 23 \mathrm{ml} / \mathrm{min})$.

1. Holweger K, Lipp HP, Beijnen JH et al. Evaluation of a non cystatin-C-based novel algorithm to calculate individual glomerular filtration rate in cancer patients receiving carboplatin. Cancer Chemother Pharmacol 2010. DOI 10.1007/s00280-010-1537-0. Published on line on 07 december 2010.

2. Stevens LA, Nolin TD, Richardson MM, Feldman HI, Lewis JB, Rodby R, Townsend R, Okparavero A, Zhang YL, Schmid CH, Levey AS; Chronic Kidney Disease Epidemiology Collaboration. Comparison of drug dosing recommendations based on measured GFR and kidney function estimating equations. Am J Kidney Dis. 2009 Jul;54(1):33-42. Epub 2009 May 17.

3. Calvert AH, Newell DR, Gumbrell LA, O'Reilly S, Burnell M, Boxall FE, Siddik ZH, Judson IR, Gore ME, Wiltshaw E (1989) Carboplatin dosage: prospective 
evaluation of a simple formula based on renal function. J Clin Oncol 7:17481756.

4. Romero I, Perayre M, Roca M, Rey M, Martin-Comin J, Clopés A. Comparación de las dosis de carboplatino obtenidas mediante la estimación de la tasa de filtración glomerular. 54th Congreso de la Sociedad Española de Farmacia Hospitalaria (2009) [Abstract].

5. De Jonge ME, Mathot RA, Van Dam SM, Beijnen JH, Rodenjuis S. Extremely high exposures in an obese patient receiving high-dose cyclophosphamide, thiotepa and carboplatin. Cancer Chemother Pharmacol 2002; 50: 251-5.

Differences between real and adjusted body weight (ABW) Clcr estimation in obese patients included in Holweger et al study. BMI: body mass index; SCr: serum creatinine; CG: Cockcroft-Gault; CG-ABW: Cockcroft-Gault using adjusted body weight. 


\begin{tabular}{|c|c|c|c|c|c|c|c|c|c|}
\hline Patient & Sex & $\begin{array}{c}\text { Age } \\
\text { (years) }\end{array}$ & $\begin{array}{l}\text { Weight } \\
(\mathrm{kg})\end{array}$ & $\begin{array}{c}\text { BMl } \\
(\mathrm{kg} / \mathrm{m} 2)\end{array}$ & $\begin{array}{c}\mathrm{SCr} \\
(\mu \mathrm{mol})\end{array}$ & $\begin{array}{c}\mathrm{eClcr}(\mathrm{CG}) \\
(\mathrm{ml} / \mathrm{min})\end{array}$ & $\begin{array}{c}\text { eClcr ABW (CG- } \\
\text { ABW) (ml/min) }\end{array}$ & $\begin{array}{c}\text { eClcr } \\
\text { carboplatin } \\
\text { calculated } \\
\text { dose }(\mathrm{mg})\end{array}$ & $\begin{array}{c}\text { eClcr ABW } \\
\text { carboplatin } \\
\text { calculated } \\
\text { dose }\end{array}$ \\
\hline 1 & $F$ & 69 & 90 & 36,1 & 98 & 69 & 50 & 465 & 375 \\
\hline 2 & $\mathrm{~F}$ & 65 & 84 & 30,5 & 80 & 83 & 66 & 534 & 457 \\
\hline 3 & $\mathrm{~F}$ & 57 & 79 & 30,9 & 80 & 56 & 68 & 550 & 464 \\
\hline 4 & $F$ & 56 & 90 & 33,5 & 71 & 111 & 85 & 676 & 551 \\
\hline 5 & $F$ & 47 & 103 & 37,8 & 80 & 125 & 91 & 746 & 580 \\
\hline 6 & $\mathrm{~F}$ & 53 & 90 & 30,1 & 71 & 115 & 94 & 696 & 597 \\
\hline Mean & & 58 & 89 & 33,1 & 80 & 93 & 76 & 611 & 504 \\
\hline SD & & 8 & 8 & 3,3 & 10 & 28 & 17 & 101 & 78 \\
\hline
\end{tabular}

